NICE Working Paper,

Radboud University

Version 2, Autumn 2006

\title{
Variation in Labor Market Participation of Married Women in Turkey
}

\author{
Ayşe Gündüz-Hoşgör ${ }^{a}$ \\ Middle East Technical University \\ hosgor@metu.edu.tr \\ Jeroen Smits ${ }^{b}$ \\ Radboud University Nijmegen \\ j.smits@fm.ru.nl
}

\footnotetext{
a Department of Sociology, Middle East Technical University, Ankara 06531, Turkey.

Phone +90 3122105985 , fax +90 3122103124

${ }^{\mathrm{b}}$ Department of Economics, Radboud University, P.O. Box 9108, 6500 HK Nijmegen, The Netherlands. Phone, +3124 3612319, fax +3124 3612379, Website: www.qqqq.nl
} 


\section{Variation in Labor Market Participation of Married Women in Turkey}

We explore the role of paid work in women's empowerment in Turkey by analyzing the variation in employment status and occupational position of Turkish women according to socio-economic and geographic background characteristics, characteristics of their marriage, and gender role attitudes. Being employed is seen as a major instrument in making women less dependent of their families and free them from the suppressing influence of patriarchal ideologies. However, only 35\% of married Turkish women is gainfully employed and half of them works as (family) farm worker. Women engaged in the formal economy are more highly educated, have husbands with higher occupations, have fewer children, live in the West and urban areas, are less suppressed by their families and have less traditional gender role attitudes. Not speaking Turkish is a major obstacle to economic independency for ethnic women. Findings basically support the U-curve hypothesis which predicts that with increasing modernization female employment first decreases and then increases, However, the effects of modernization are overshadowed by the strong influence of patriarchal ideology that tends to confine Turkish women to the private domain. The major way out of the web of patriarchal restrictions seems to be via the educational channel. 


\section{Introduction}

The labor market participation (LMP) of women varies much among developing countries. There are countries were over 60 percent of adult women is gainfully employed (e.g. Kazakhstan, Cambodia, Ghana), but there are also countries (e.g. Algeria, Egypt, Iran) where less than 20 percent of women is engaged in one or another form of paid labor (ILO, 2006; UN, 2007). Given the central role of work for the empowerment of women, it is important to increase our understanding of the factors that promote or hinder female employment in developing countries. In this paper, we aim to do this by studying the factors that influence women's LMP in Turkey. Turkey is a very interesting case for such a study, because it combines a low level of women's LMP with a strong polarization among the women who are employed. Whereas only one third of married women in Turkey declares themselves to be employed, and many of these women work as (often unpaid) family workers, there is also a small group of highly educated professional women who occupy high-status white collar jobs in the formal economy (ILO, 2006; Gündüz-Hoşgör, 1997; SIS, 2006; Tansel, 2002). To gain insight into the mechanisms underlying this variation, we analyze the effects of socio-economic, cultural, demographic, and geographic background factors on the employment status and occupational position of women in Turkey. Being employed is seen as a major instrument in making women less dependent on their families, which may free them from the suppressing influence of the patriarchal ideologies that stress a subordinate position of women.

Central in the paper is the labor market position of married women, categorized as "housewife", "unpaid or paid farm worker", "manual worker", "lower nonmanual worker" or "upper nonmanual worker". Using a large individual-level data set, we determine the effects of characteristics of the women themselves, of their husbands and the households they are living in, and of their (family-)backgrounds on their chances of being in each of these labor market positions. We also study whether there are differences in labor market position between women living in different regions of Turkey, between women living in cities or in the countryside, and between migrant women (who 
may be less influenced by their families) and woman who stayed in their region of origin.

In the next section, we present an overview of the literature relevant for women's LMP in developing countries. After that, we focus on the situation in Turkey.

\section{Theoretical Background}

Regarding the factors that may influence the labor market position of women in developing countries, several theoretical positions can be distinguished. First, there is classical modernization theory, which relates a country's rate of female LMP to the country's phase in the modernization process by which agrarian societies are transformed into post-industrial ones. Processes that go together with industrialization -- like changes in the occupational structure, increasing educational opportunities, decreasing fertility, urbanization, more pervasive mass communication and the diffusion of values that stress equality of men and women -- were expected to improve the status of women, who would enter paid labor, get more education, enter the political domain and eventually get the same rights as men (Lerner, 1958; Kerr, Dunlop, Harbison \& Myers, 1960; Klein, 1963; Wilensky, 1968; Shorter, 1973; Inglehart \& Norris, 2003).

However, these predictions of classical modernization theory are not unequivocally supported by empirical research. In fact, most studies on the effect of modernization on women's LMP found an nonlinear relationship, with decreasing LMP in the earlier phase of modernization and increasing LMP in the later phase (e.g. Sinha, 1967; Durand, 1975; Tilly \& Scott, 1978; Pampel \& Tanaka, 1986; Psacharopoulos \& Tzannatos, 1989; Rau \& Wazienski, 1999; Lincove, forthcoming). This U-curve relationship has been explained by the different processes taking place in the early and late phases of modernization. According to Boserup's (1970) women in development perspective, in preindustrial societies productivity differences between men and women were negligible. As most of the production took place at home, women could actively take part in it and combine work with caring duties. However, in the early industrialization phase, the possibilities of women to be economically active 
were greatly reduced. The specialization and mechanization of farming reduced their possibilities to contribute to the family business. At the same time, the newly emerging industrial jobs offered no real alternative to them, as their caring duties bounded them to their homes and most new jobs required physical strength and therefore were not considered to be compatible with women's roles at home. Women's employment chances were also reduced by their lower levels of education and training and by sex discrimination at the labor market (Scott \& Tilly, 1975; Boserup, 1977, Pampel \& Tanaka, 1986; Rau \& Wazienski, 1999). The upward part of the U-curve has been related to a number of factors and processes taking place in advanced industrial societies that promote the employment of women. Examples are the expansion of the tertiary sector which offers more job opportunities to women --, the increasing dependency of household on women's income, the lower fertility and higher educational levels of women, the rise in female political power, and the reduction of discriminatory practices at the labor market (Boserup, 1970; Oppenheimer, 1970; Davis, 1984; Psacharopoulos \& Tzannatos, 1989; Forsythe, Korzeniewicz \& Durrant, 2000).

The U-curve hypothesis seems to give a good explanation for the low participation rates of women in Turkey; the country might still be in the intermediate phase of modernization, when female employment rates are lowest. However, it does not explain why women's LMP in Turkey is lower than in other regions at similar levels of development, like South-East Asia or Latin America (Youssef, 1974; Forsythe et al., 2000; Morrissin \& Jütting, 2005). Additional explanations might be found in the influence of cultural factors and specific labor market circumstances.

The most important cultural factor influencing women's position and LMP in Turkey and its neighboring countries is patriarchy. The Middle Eastern countries, including Turkey, are part of what has been called the "patriarchy belt" by Caldwell (1978), which included besides the North African and Middle Eastern Muslim countries also South and East Asian countries with a Hindu or Confucian background. The form of patriarchy in these countries is characterized by patrilocal extended households, where all power is in hands of the senior male, and property, residence and descent proceed through the male 
line (Moghadam, 2004). In this "classical patriarchal system" (Kandiyoti, 1988), that has functioned for many centuries in the rural areas of these countries, girls are given in marriage at a young age and then move to the household of their husband's family, where they are subordinated to all men and senior women. The major task of women is producing offspring, and the power they eventually can obtain within this system is through their sons. The major task of the men is to provide income and security for their families. There is a strict separation between the male and female domains, with men operating in the public sphere and women in the private sphere. Given the strong emphasis on the male breadwinner role, the high fertility and low educational level of women, and their restriction to the private domain, women's employment in the formal economy is very low under this system. Although the system has come under pressure since the onset of modernization - reduction of employment possibilities in rural areas and massive migration to the cities have eroded the extended family system and the male provider role - its ideology is still broadly upheld and its influence strongly present in the legal framework and institutions of most Middle Eastern countries (Moghadam, 2004).

A final factor influencing women's LMP might be found in the specific economic opportunity structure of the region in which they live. We already mentioned that the possibilities for female employment are higher in the tertiary sector. Especially public sector jobs are favorable to women's employment, because the shorter and more regular hours are more compatible with domestic duties and governmental agencies are less able to discriminate on the basis of sex (Assaad \& Arntz, 2005). But also in manufacturing there are some industries that offer possibilities for women. Female employment is traditionally higher in export-oriented 'light' industries, like textile, garments and food processing, that are more compatible with traditional women's roles than in import-substitutive heavier industries (Horton, 1999; Kabeer \& Mahmud, 2004; Baslevent \& Onaram, 2004; Ross, 2006). According to Ross (2006), light industries are favorable to women's employment, because they require no physical strength and little training or specialized skills. They can also grow 
quickly so that no male jobs are replaced, and they are operating in very competitive markets and hence seek labor at the lowest costs.

For many uneducated women, informal sector employment, like cleaning and home-based production, offers them the opportunity to be economically active and gain some independence by contributing to family income (ILO, 2002; Chen, Sebstad \& O'Connell, 1999). Globalisation has been accompanied by an informalisation of employment in developing countries and has led to an increase of "putting out systems" in which firms subcontract work to small enterprises, including women working at home (Sethuraman, 1998; Standing, 1999). Especially in Middle Eastern countries, where women even more than elsewhere are restricted to the private domain, this may have increased female employment opportunities.

\section{Women in Turkey}

Modernization movements that under influence of the industrial and French revolutions already began in the nineteenth century in the Ottoman Empire and that continued in the Turkish state after the War of Independence (1919-1923), played an important role in the advancement of women's rights in Turkey. Sex equality in employment was promoted through government policies shaped around the principles of 'modernization' and 'westernization' (Ozbilgin, Tatli, \& Küskü, 2005). Muslim family law (polygamy, divorce, child custody, and rules related with governing marriage) became subject to challenge by the reformers in order to improve the women's position (Lewis, 1968; Ahmad, 1982; Kandiyoti, 1988; Çakir, 1994; Baykan, 1994). According to Moghadam (1993), "change in family law is a significant index of social change in the Middle East, a barometer of the internal debate within Islam, and an illustration of the capacity for Islamic reform. It also indicates the degree of "state feminism".

Mass schooling, the state-sponsored education system, and policies aimed at increasing female employment to a certain extent created a new educated and independent woman in the urban areas of Turkey. These educated women made great contributions to the nation-state building processes at that time. The emancipation of women through education and work was linked to the 
nationalist revolutionary movements, and as a result of these movements the status of women has improved (Jayawardena, 1986).

However, the introduction of these new possibilities for women did not mean that they quickly became widespread or were instantly and easily embraced by the majority of the population. For the large group of rural women, especially the ones living in the East of the country, there was not much change, because the modernization attempts were blocked by the religious and ethnic tribal leaders and the possibilities to go to school were limited because of the lack of a good schooling infrastructure (Tekeli, 1982; Gündüz-Hoşgör \& Smits, 2007). Kurdish and Arabic ethnic women also had (and many still have) another disadvantage: they were speaking their local languages at home. This meant that the ones who could not attend school missed the opportunity to learn Turkish. Nowadays still about a quarter of the Kurdish and Arabic women, or one in every 25 women in Turkey, cannot speak Turkish. This means that they are dependent on their male household members (who almost all speak Turkish) for information about society and their legal rights (Smits \& Gündüz-Hoşgör, 2003).

The differences among women from different background in Turkey were strengthened by the process of mass migration from the countryside to the urban areas, which accompanied the mechanization of agricultural production. Whereas in the 1920s the large majority (75\%) of the population was living in the countryside, by 2000 this proportion has decreased to only $30 \%$. As a result of this development, broadly speaking, nowadays three major groups of women can be distinguished with different life styles. At the upper end of society, there is a small elite of educated women with good positions at the labor market. These women generally have middle or upper class family background, which gave them the opportunity to benefit most from the social changes. Their higher educational level opened the way to middle-class and higher-class occupations and this group currently has a considerable share of certain high-status, formerly male dominated occupations like law, medicine, judgeship, and teaching.

Besides these modern women who have profited much from the opportunities created by the modernization policies of the Turkish state, there is 
a large group of uneducated women in the countryside whose daily lives have not yet been influenced much by the changes. These women are still heavily under the influence of their families and the patriarchal traditional values. Still, as we saw in the preceding section, these women may have some freedom and economic importance, because they perform a range of essential agricultural activities as family workers.

In-between these two groups, there is a third group of women who may be in the most difficult positions, as they are in a transitory stage. The large migration streams from the countryside via the local towns to the large cities has transformed many uneducated Turkish women, who used to have some economic independence as (family) farm workers, into full-time housewives. As far as these migrant women become economically active again, it is in low-paid work in the urban informal economy (like domestic work or in unofficial mobile and/or home-based economic units) or in the labor-intensive formal industry (Gündüz-Hoşgör, 1997; Erman, 1998). The position of this third group of women is especially difficult, because on the one hand they lost the relative security of country life, while on the other hand they have little possibilities to make effective use of the opportunities offered by city life, as most of them missed the schooling opportunities in the villages where they grew up. It is this third group of women which can be expected to suffer most from the globalization process.

During a period of fast urbanization, the traditional and the modern values are laid on top of each other and expected to function cohesively. For the newly urbanized, this may result in acceptance or rejection of the "modern" issues. Acceptance means that formerly rural women come to work in the formal sectors, become financially independent, and gain self-confidence. Rejection, on the other hand, manifests itself as a defense mechanism for protecting one's identity against the overwhelming power of the urban environment (Göle, 1991, Baykan, 1994, Ilyasoğlu, 1994). They may draw back in the safety of the household and of the community of migrants from the same region and of the traditional values with which they grew up.

Which position will be taken, may depend to a certain extent on the schooling and employment opportunities the women have. Previous research 
suggests that educated women in Turkey less often hold up traditional gender roles and are more "independent" (have less children, higher divorce rates and less often only a religious marriage) than uneducated ones (Gündüz-Hoşgör \& Smits, 2007, Smits \& Gündüz-Hoşgör, 2003). Schooling, therefore, may create a way out of the web of patriarchal restrictions in which these women are caught. To what extent the labor market position of women also plays a role remains to be seen. Erman (1998) finds evidence that if the husband is not successful in providing for his family, migrant women may strengthen their position in the family by taking a job in the informal sector. When the husband is able to provide some regular income, the possibilities for women to gain some independency are much lower.

\section{Female employment in Turkey}

In line with the prediction of the U-curve hypothesis, the process of modernization and urbanization in the second half of the last century in Turkey has led to a decrease of female employment. The outflow of women from agriculture was only partly compensated by an increase of employment in the modern sectors of the economy (Tansel, 2002; ILO, 2006). Table 1 shows that as recently as 1985, agriculture was still the most important employment sector in Turkey, with 45 percent of the total Turkish labor force and 79 percent of the female labor force employed in this sector. Since then, these percentages decreased considerably to 30 and 52 percent respectively.

In the same period, the percentage of employed females working in manufacturing almost doubled. This might in part be due to the change in industrial policy of Turkish government. Until 1980, there was a strong focus on import substitution heavy industry, with little employment possibilities for women. Since then, Turkey has chosen to participate more fully in the global economy. With the impact of neo-liberal policies of globalization, trade barriers and capital restrictions came down, export competitiveness was encouraged and state-run enterprises were privatized. As a result, female employment in light manufacturing could increase, as had been the case in other countries following such a strategy (Standing, 1999; Tansel, 2002; Ross, 2006). 
Besides in manufacturing, female employment also rose in services. The percentage of employed women working in the social and personal services (including public sector employment) doubled between 1985 and 2005 and the percentage working in commercial services even quadrupled. For example, in the banking sector women's participation rates increased from $24 \%$ to $42 \%$ between 1988 and 2001 (TBB, 2002), because organizations in this sector adopted secular and global policies in their recruitment practices and the demand for skilled employees in this sector was met by the increasing educational level of Turkish women (Özbilgin \& Woodward, 2004).

Still, the rise in the percentage of employed women working in nonagricultural sectors is smaller than it may seem from the figures in Table 1, because at the same time the total female activity rate decreased substantially (bottom line Table 1). In 2005, no more than 30 percent of Turkish women aged 20-49 were gainfully employed. This suggests that the cultural factors that restrict women's possibilities to be active in the public domain still play a major role in Turkey. According to Ozbilgin et al. (2005), the Turkish state policies encouraging female employment in professional occupations did not question the traditional family ideology positioning women as the prime domestic workers and hence left the deeply rooted patriarchal assumptions unchanged (see also Kandiyoti, 1997; Tekeli, 1982).

Besides the persistent influence of patriarchal ideology, also other factors may play a role, like the low educational level and high fertility of many Turkish women, or the lack of jobs considered appropriate for women in the local labor market structure.

\section{Regional differences}

The theoretical arguments regarding the effects of modernization on female employment not only apply to differences among countries, but also to differences among regions within countries, which also may differ in modernization, strength of patriarchal influence and labor market structure or sector of employment. In Turkey, there a major differences between urban and rural areas and between different parts of the country. In the literature, the 
country is generally divided into West, South, East, North and Central (TDHS 2000). The major difference with regard to the factors that may influence women's LMP is between the West and the East. The West is the most advanced region of Turkey. It is the most densely populated and urbanized region, as it includes Istanbul (the country's largest city with around 13 million inhabitants) and Izmir (the third largest city with 3 million inhabitants). The early industrialization attempts took place in the Western regions. The infrastructure necessary for regional development (such as roads and schooling) was build up there earlier than in the other parts of Turkey and the mechanization of agriculture and its connection to the market economy took already place in the 1950s. The highly diversified and rapidly growing manufacturing industry attracted many people from the less developed parts of Turkey to the cities of the region. Given the relatively high level of development and favorable labor market of the West, women in this region are expected to have higher labor force participation rates and higher jobs than women in the other parts of the country.

The East of Turkey is the least developed region of the country. This region is generally divided into an eastern and a south-eastern part. In the eastern part, the most important economic activity is husbandry. Crops are generally produced only for household consumption. The average size of the agricultural holdings is small compared to other regions and the lands are mainly cultivated by the landowners. Another important feature of agriculture in the East is the low level of mechanization. The number of people living in urban areas and the rate of population growth are also low. In some parts population growth is even below zero, because of out-migration. Per capita income is the lowest of all regions of Turkey.

The south-eastern part shows similarities with the eastern part in terms of lack of industrialization and infrastructure. In the Southeast, the villagers live either in the high mountains or at plains. In the mountains, the majority of the villagers own the land on which they work, whereas on the plains the tribal leaders or "Aghas" own the land. Until recently, an important characteristic of the villages in this region was their tribal structure and most people lived under 
the authority of their religious leaders (Sheiks). Because of economic insufficiency, the region experienced high levels of internal migration to the larger cities. In some regions (especially in Diyarbakir) this migration process was strengthened in the last decades as a result of the political unrest between the separatist Kurdish Worker Party (PKK) and the State's security forces and forced many people to migrate.

Earlier research found the situation of the women in the East of Turkey to be worse than in other regions with regard to almost all indicators of women's status that were used (Gündüz-Hoşgör \& Smits, 2007). In the countryside of that region, one third of the married women is not able to speak Turkish, the country's official and dominant language, and one third has no official civil marriage, which puts them in a disadvantage position in terms of legal rights.

\section{Data and Methods}

\section{Data}

We use data from the 1998 Turkish Demographic and Health Survey (TDHS). This survey is part of the demographic and Health Surveys (DHS+) program which provides data and analyses on the population, health, and nutrition of women and children in developing countries (DHS+ 2007). The DHS+ surveys use nationally representative samples of households and consist of at least a household survey and a women's survey. In the current paper, we use the data from the TDHS women's survey. The females in the data set are a representative sample of all females aged 15 to 49 in Turkey. The males for which information is available are the husbands of married females. We restrict our analyses to married women. The total number of women included in the analyses is 6,189 .

\section{Method and variables}

The effects of household characteristics on the labor market position of women are studied using bivariate cross tabulations and multivariate logistic regression analyses. Labor market position was measured with five mutually exclusive categories: (1) Not working/housewife, (2) unpaid or paid farm worker, (3) 
manual worker, (4) lower nonmanual worker, (5) upper nonmanual worker. We analyze the variation in labor market positions according to (socio-economic and cultural) characteristics of the women themselves, of their husbands, and of the households in which they are living. We study whether there are differences between women living in different regions of Turkey, and with regard to urbanization, and between migrant women and women who stayed in their region of origin.

Age of the women is measured in three categories: (1) 15-25, (2) 26-35, (3) 36-50, or in years. For educational level we use four categories: (1) Less than completed primary, (2) Completed primary (3) At least some secondary, (4) At least some tertiary. Literacy of the women is measured by three categories: (1) Reads easily, (2) Reads with difficulty, (3) Cannot read. Occupation of the husband is measured with four categories: (1) Farm, (2) Manual worker, (3) Lower nonmanual worker, (4) Upper nonmanual worker. In the bivariate analyses, number of children is measured with four categories: (1) none, (2) 1 or 2, (3) 3 or 4, (4) 5 or more, and age of children with three categories: (1) None, (2) Also children below 6, (3) Only children 6 and over. In the multivariate analyses, these variables are combined into: (1) none, (2) 1-2 including under age 6, (3) >2 including under age 6, (4) 1-2 only over age 6, (5) >2 only over age 6. Living in an extended family is measured with a dummy indicating whether (1) or not (0) there are grandparents and/or other close relatives living in the household. Presence of the husband is measured with a dummy indicating whether (1) or not (0) the husband is living away from home.

The geographic characteristics are region and urbanization/migration status. For region, five categories are used: (1) West, (2) South, (3) Central, (4) North, and (5) East. Urbanization/migration status is coded into five categories: (1) Always lived in city, (2) Migrated to city 11- 45 years ago, (3) Migrated to city 010 years ago, (4) Town (5) Countryside.

As socio-cultural factors, we use information about the marriage of the married women, whether or not they speak Turkish, and their answers to four indicators of gender role attitudes. Age at first marriage and age got first child are measured with three categories: $(1)<16$, (2) 16-20, (3) $>20$. In the 
multivariate analyses for age at first marriage a dummy variable is used which indicates whether (1) or not (0) the women married under age 16 . The other marriage variables are dummies indicating whether (1) or not (0) there is a blood relationship with the husband, there was a bride price paid at the wedding, there was only a religious marriage ceremony, or the marriage was arranged by the family. To indicate women who were not able to speak Turkish, we used a dummy variable coded ' 1 ' for women with another language than Turkish as mother tongue, who stated that they were not able to speak Turkish and coded ' 0 ' for all other women. The traditional gender role attitude variables are dummies indicating whether (1) or not (0) the female agreed with the following statements "Important decisions should be made by men", "Men are wiser than women", "Women should not argue with men", and "It is better for a male than for a female child to have education." In the multivariate analyses, a traditional gender role attitude index is used, constructed by taking the average of the standardized version of these four variables.

\section{Results}

Table 2 present the percentages of women in the different labor market position according to characteristics of themselves, their partner, their children and their households. At the bottom line of this table, we see that almost two-third of married Turkish women aged 15 to 49 is not engaged in paid employment. About half of the women who are employed are engaged in agricultural work $(18 \%)$ and the other half is employed in the formal economy (17\%). Of the women employed in the formal economy, 8 percent works as manual worker, 5 percent has a lower nonmanual occupation and 5 percent an upper nonmanual occupation. That means that the group of higher educated women with professional or managerial positions consists of about 5 percent, or one in twenty, of the married women.

The second column of Table 2 makes clear that the proportion of married women who are housewives does not differ much among the categories of most of the explanatory variables. The percentage of housewives is clearly lower among the women with tertiary education and the women of which the husband 
is working in farming. The other differences are rather small, suggesting that being a housewife is an accepted role for women at most levels of Turkish society.

Interestingly, the two exceptional categories constitute two very different situations. As could be expected, the wives of farmers are almost all working in farming. The women with tertiary education, on the other hand, are almost all working in the formal economy and more than half of them in an upper nonmanual occupation. These figures suggest that of the women in Turkey who manage to get access to tertiary education, many complete their education and reach upper nonmanual positions. In recent years, women's success rate in the nationally competitive University entrance examination has even surpassed that of men (Acar, 2004, Dayığlu \& Türüt-Aşık, 2004). The figures suggest that women's empowerment through employment in Turkey requires tertiary education, which means that this is mostly an option -- both culturally and economically -- for the middle or upper class urban women.

On the other hand, we see that non-employment is higher among the youngest women. As the sample includes only married women, among the young women there is a strong overrepresentation of women who married young. Economic difficulties and the patriarchal ideology usually reinforce each other and lead to the school drop-out of the daughters of the poor. Many of these poor girls get married and have their first child at a very young age, which reduces their labor market possibilities considerably. This becomes also clear if we look at the effects of the number and age of children in Table 2. In all categories of women with children, the non-employment percentages are higher and the percentages of employment in the formal economy are lower than for women without children. Hence, the lack of (or limited) welfare state facilities (like family or childcare support) and the existing patriarchal ideologies may go hand in hand and limit the access of women to the public sphere through education and employment.

Having children clearly reduces the chances of employment at the higher levels. Of the women without children, more than 10 percent has an upper nonmanual job whereas this percentage for women with more than two children 
is less than two. As the gender and development approach suggests, when women are joining work in the formal sector, they tend to give up responsibilities in the private domain (Ecevit, Gündüz-Hoşgör \& Tokluoğlu, 2003). Regarding the age of the children, we see that participation in lower non-manual job is especially reduced when there are young children at home. This indicates that this is a category with a higher than average tendency to drop out of the labor force upon getting a child.

In terms of the education and occupation of the husbands, we observe that upper nonmanual women are married mostly with upper nonmanual men and with men who have at least tertiary education. This probably is due to educational assortative marriage, as there is rather strong educational homogamy in Turkey (Gündüz-Hoşgör \& Smits, 2002). We also see that women living in extended families more often are employed in farming, whereas women living in nuclear families have a higher propensity to work in nonmanual and especially upper nonmanual occupations.

Farm work is generally carried out by husbands and wives together. When the husband is employed in farming, most often (59 percent) the wife is working there too. Also women with more children and women living in extended family structures tend to be more often employed in farming. For non-employed women and women working in farming, the husband is somewhat more often living away from home, for instance to work as unskilled worker in construction business, in seasonal agriculture work (like cotton or tobacco picking activities), or in the tourist sector (Keyder \& Buğra, 2003).

With regard to the geographic characteristics, Table 3 makes clear that women in the West (where industrialization started) more often are employed in the formal economy and especially in manual occupations. In this region, a quarter of the women has a formal job. In the east, on the other hand, only eight percent of the women is employed in a formal job, and the proportion of women who are housewives is almost 80 percent. The LMP of women is highest in the North, where 55 percent of the women is employed, of which the large majority $(42 \%)$ in farming. The husbands of those Northern women are often away most 
of the year, to work in constructions in metropolitan cities like Istanbul and their wives stay at home and take care of the family farm.

With regard to urbanization and migration status of the women, we see that the longer women have lived in a city environment, the more chance they have to work in the formal economy and in upper nonmanual jobs. The ones who recently migrated to the city tend to be most often employed in manual occupations. Also non-employment is with 77 percent highest among these newcomers, although it is also high among the groups who have been living longer in the city. The main reason for this seems the fact that there is hardly any agricultural work in the urbanized areas, which in the parts of the country where it is available forms the most important source of work for the large group of uneducated women. Women without education in the city don't have this alternative and therefore often have no other option than becoming a housewife or to do something in the informal sector.

Table 4 shows the variation in women's labor market positions according to characteristics of their marriage. Woman who married or got their first child when they were over age 20 have a much higher chance of being employed in the formal economy than women who married or got their first child at a younger age. The chances to work in the formal economy are also much higher for women who are not related to their husbands; at whose wedding no brides money was paid, who have a civil marriage and/or who arranged their marriage themselves (instead of their families or matchmakers). These findings imply that there is a positive association between women's autonomy and empowerment and their employment in the formal economy.

Table 5 also supports this finding in terms of the gender role attitudes of the women. Women who don't agree with the statements that "Important decisions should be made by men", "Men are wiser than women", "Women should not argue with men" and that it is "Better for male child to have education" have a more than two times higher chance of being employed in the formal economy and especially of being employed in a non-manual job. Table 5 also points out that speaking Turkish is sort of "a must" to join the formal economy and may be 
even important for farm work. Of the women who could not speak Turkish, only 14 percent were employed, of which only two percent in the formal economy.

\section{Reason for not being employed}

The very low LMP found among the married Turkish women raises the question of why such a large proportion of these women is not employed. Because in the TDHS the women who are not employed were asked for the main reason for their non-employment, we can get an idea of this. Table 6 presents the distribution of their answers. A little more than one-third of the women gives "looks after children" or "housework" as main reason for not being employed; 27 percent answers that their husband or elders don't want this; 11.5 percent answers that they don't need to work, 11 percent answers to be unable to work because of sickness, handicap, or unemployment, 4.5 percent mentions to have "no talent or education", and 8 percent gives other reasons. Although most answering categories are rather vague and these kind of "after-the-fact" motivations are notoriously unreliable, the fact that more than a quarter of the women says that they don't work because "their husband or elders don't want" suggests that family pressure plays a role of importance in explaining the low LMP of women in Turkey.

\section{Multivariate Analysis}

The results presented so far show that there are important differences among women in Turkey in terms of their labor market situations. However, because many of the variables studied so far may be related to each other, the presented percentages do not reveal which factors are important and which are less important in explaining the women's labor market position. The fact that in the eastern part of the country more women are not employed may for example be related to their lower educational level, their more traditional family background, or to the fact that they have more young children at home.

To gain more insight into the importance of the various factors in explaining the variation in the labor market position of the women, we conducted multivariate logistic regression analyses in which the effects of independent 
variables on four aspects of women's labor market position were studied: (1) whether or not the women is housewife, (2) whether or not she is employed in agriculture, (3) whether or not she works in formal employment, and (4) whether or not she works in an upper non-manual occupation. We have chosen for separate logistic regression analyses instead of a multinomial logit model, as there is not a clear reference category with which the odds of being in the other categories can be compared. The most obvious reference group, the non employed, has the disadvantage that it is not clearly separated from the women engaged in farming. Most farms in Turkey are small family farms where it is rather normal that the woman combines doing the household chores with farm work. This makes it difficult to say whether these women are employed in farming or housewives and there may be considerably overlap between these categories. We therefore have chosen to use ordinary logistic regression models analyzing the odds of being in a category versus being not in that category. This way of modeling has the additional advantages that the coefficients are easily interpretable in terms of the choices of being in the respective employment category or not and that a clear picture is obtained of the way in which the women in each of the categories differ from all other women.

The explanatory variables tested in these analyses are respondent's age and education, husband's education and occupation, presence and age of children, region, urbanization/migration, whether husband is away from home, whether the respondent can speak Turkish, whether the respondent is related to the husband, whether the couple arranged the marriage by themselves, whether bride money was paid at the wedding, whether the couple only had a religious marriage, whether the woman married before age 16, and the woman's gender role attitudes measured by the constructed index. Of the variables included in the analyses, only the ones that contribute significantly to the explanation of the variation in the dependent variables are selected into the final models.

Table 7 presents the results of the logistics regression analyses. For each effect we present both the logistic regression coefficients and (between 
bracelets) their multiplicative versions. The logistic versions of the coefficients clearly show whether an effect is positive or negative but are not easily interpretable in terms of effect size. The multiplicative versions can be interpreted more easily in this respect. They show how many times higher or lower the odds of being in category one of the dependent variable is when the value of the independent variable increases by one step. A value of 1 means no effect. For example, in Model 1 the value of 0.57 for women with at least some secondary education means that for this category the odds of being a housewife is 0.57 times the value of the reference category (less than primary); hence women with this educational level have a 43 percent lower odds of being a housewife than women in the reference category. Similarly, the value of 1.48 for husbands with at least some secondary education means that for women with such a husband the odds of being a housewife is 1.48 times as high as for women whose husband has less than primary education.

The coefficients for Model I show that women who have less than primary education more often are housewives than the ones who have at least completed primary or a higher educational level. Having at least some tertiary education reduces the chance of being a housewife rather much. The effect of the educational level of the husband is significant for the two highest categories. Because this effect is positive, we can conclude that being married to a husband with secondary or more education increases the chance of being a housewife. Regarding the occupation of the husband, women have the lowest chance of being a housewife when the husband is employed in farming. As stated above, on the many small family farms women often combine the household chores and childcare with farm work.

As was expected, the chance of being a housewife is higher in households with young children. It is also higher if the woman lives in the Eastern region of Turkey (the reference category of the region variable). This last finding is in line with earlier research indicating that in the countryside of the East of Turkey the LMP rates of women are much lower than everywhere else in the country (Gündüz-Hoşgör \& Smits, 2007). Even with regard to employment in farming, women in the East have a weaker economic position than elsewhere. In 
contrast, the chance of being a housewife is lowest if the woman lives in the North of the country.

Women living in the city have a higher chance of being a housewife than women living in towns or in the countryside. This chance seems independent of the time that the woman already lives in the city. Women who cannot speak Turkish and women who only had a religious marriage or for whom bridesmoney was paid at the wedding (and hence who are controlled more by their families) also have a higher probability of being not employed. The only finding which is not directly in line with expectations, is that women with more traditional gender role attitudes have a lower chance to declare themselves housewives. This is probably due to the fact that many traditional women are living in the countryside at small family farms and hence declare themselves as being employed in farming (as is indicated by the significantly positive effect of this variable in the second column of Table 7).

Model II presents the coefficients of the explanatory variables that were found to contribute significantly to the explanation of the variation in farm employment. Women who have less than primary education involve more in agriculture than the ones who have at least some secondary education. The category at least some tertiary is also highly negative, but not significant (probably because there are hardly any women with this educational level employed in farming).

The educational level of the husband has no influence on whether the woman is employed in farming, but -- as could be expected -- having a husband working in farming has a very strong positive effect. The presence and age of children has no effect on employment in farming, which is no surprise given the fact that farm work can be combined well with taking care of the children. Region and urbanization do have effects. Interestingly, women in the East have the least chance of being employed in agriculture. That women in towns and countryside are more employed in agriculture than women in cities, is not surprising. However, the finding that speaking Turkish is important for working in farming is unexpected. It suggests that even the possibility to gain some economic importance by contributing to the family farm is not available to many 
women who cannot speak Turkish. The same is true for women who have only a religious marriage.

Model III presents the coefficients of the explanatory variables found to contribute significantly to the explanation of the variation in formal employment. The likelihood of being employed in the formal economy increases significantly with the educational level of the woman, but not with the educational level of her husband. In fact, after controlling for the other factors in the model, the effect of the husband's educational level is negative: employment in the formal economy is highest for women whose husband has less than primary education. This finding might mean that husbands with some education prefer their wife to stay at home instead of being employed. It also suggests that the strong positive effect of husband's education on participating in the formal economy found in the bivariate analyses was in fact the result of the positive effect of the education of the woman herself combined with the fact that highly educated women in Turkey tend to be married to highly educated husbands.

Women whose husbands are in formal occupations have more chance of being employed in formal economy than the ones whose husbands are farmers. If the husband has a nonmanual occupation the chance that the wife is formally employed is highest. Hence, it seems that the belief that "men are the only breadwinner" continues to some extent among the working class families.

Having children, and especially having young children or having more than two children, has a negative effect on being employed in the formal economy. Having only one or two older children does not have a negative effect on participation in formal employment. With regard to region, we see again that women in the East tend to be less often employed in the formal economy than women in the West. The odds of being employed in the formal economy are lower for women whose husbands are away from home and for the ones who can not speak Turkish. Also women with traditional gender role attitudes are significantly less employed in the formal economy.

With regard to the odds of being employed in an upper nonmanual occupation, education of the woman and the occupation of her husband seems most important. The importance of her own educational level is rather obvious, 
a high occupation generally requires a high education. The importance of having a husband with an upper nonmanual occupation is less straightforward, but fits well into the idea that social mobility of women to the highest levels of society is mostly a middle and upper class phenomenon. It also is in line with theories about assortative mating and partner effects that assume that people with good prospects at the labor market tend to marry with each other and that partners may profit from each others occupational capital (e.g. Smits, Ultee \& Lammers 1996, Kalmijn 1998).

Having more than two young children reduces the chance of being employed at this level, probably because of the lack of child care facilities and traditional gender role attitudes. Also being controlled by the family -- as indicated by being married to a relative -- and having traditional gender role attitudes negatively affect the probability that a woman is employed in an upper nonmanual occupation.

\section{Conclusions}

Our results make clear that the LMP of women in Turkey is very low. Almost twothird of married Turkish women aged 15 to 49 answers to be not gainfully employed. Of the women who state to be employed, about half is engaged in agricultural work and the other half is employed in the formal economy. Our findings reconfirm the existence of important variation among Turkish women in terms of their labor market situation. On the one hand, there is a small group of educated women who occupy high-status jobs in white-collar occupations. About 5 percent of Turkish women belong to this group. On the other hand, agriculture still plays an important role as source of employment for women: about 18 percent of Turkish women answer to be employed in an agricultural job.

To gain insight into the factors in the personal and family background of Turkish women that determine whether they are fulltime housewives or engage in agricultural or formal employment, both bivariate and multivariate analyses were performed. The results of these analyses show that the women's own educational level is a major factor influencing their labor market position. The chances of being 
a housewife decrease with each step increase in educational level and the chances of being engaged in formal employment increase with each such step. For being employed in an upper nonmanual job, the woman should have at least secondary education. The women with tertiary education take in a special position. Whereas of the women with less than tertiary education two third is not engaged in any employment, of the women with tertiary education three quarter is employed and 58 percent has an upper nonmanual position. This result makes clear that the major road towards economically independence for women in Turkey is via the educational channel.

Besides the women's own educational level, also the educational level of their husband plays a role. However, the direction of this effect is different from the effect of the own educational level. If the husband has a higher educational level, the chances that a woman is a housewife are higher instead of lower. And when the husband has primary or more education, the chances that a woman is employed in a formal job are significantly lower. This supports the idea that at least part of the employed women in Turkey work out of necessity. When the need for additional income is lower because the husband has more human capital, employment seems less an option to these women, either because they are not allowed to work by their families or because of their own choice. The additional finding that the educational level of the husband has no significant effect on the woman's chances of being employed in an upper nonmanual occupation, makes clear that their husband's human capital is not much of a help for the career of highly educated Turkish women.

With regard to the occupational level of the husband, we observed that wives of farmers are less employed in the formal economy and that wives of manual and lower nonmanual workers have the highest probability of being a housewife. Women who are employed in an upper nonmanual occupation tend to have husbands who are also employed at that level. These results may imply that in Turkey the existence and practice of patriarchal ideologies varies not only among women but also among men. On the one hand, there seems to be a group of men with upper non manual occupations who support the employment of their wives, whereas on the other hand, the men with lower-level positions in the formal 
economy seem to have more reservations and to hold patriarchal values that work against the women's employment. Hence, the diversity within the country is pertinent for both men and women.

The positive effect of the presence of young children in the household on being a housewife and the negative effects on being employed in the formal economy or in an upper nonmanual occupation are in line with what is known from other parts of the world: the burden of raising children rests on the shoulders of women and reduces their opportunities at the labor market. The fact that this negative effect of children is not present for employment in agriculture is also no surprise, given the homebound nature of agricultural work. However, when these rural women migrate to the city, as has happened to millions of women in Turkey over the last decades, the possibilities to combine work at home with childcare are greatly reduced, as can be seen from the finding that three quarter of city women declare themselves housewives against less than half of countryside women.

How can our findings be interpreted in light of the theoretical ideas regarding women's employment in Middle Eastern countries presented in the beginning of this paper? Regarding the effects of modernization, the findings provide evidence in favor of the U-curve hypothesis. As Table 1 made clear, in the last decades there has been a strong decrease of female employment in agriculture which was not completely compensated by an increase of female employment in the other sectors of the economy. As a result of this development, the female activity rate decreased from 45 to 30 percent between 1985 and 2005. This finding is clearly not in line with the steady increase in female employment predicted by classical modernization theories. We also found that the proportion of employed women working in the service sectors of the economy increased from 13 to 33 percent over the last two decades. This indicates that the forces that according to the $U$ curve hypothesis will eventually turn the tide are gaining weight in Turkey. In the coming years, the reduction of female employment in agriculture will slowly decrease, as the remaining number of farm women becomes less and less. At the same time, new job opportunities for women will become available in the expanding service sector. 
Still, it remains to be seen in how many years the positive upswing of the $U$ will be reached, because the forces of economic modernization are working in a cultural environment that does not support female participation in the public domain. Our findings regarding the effects of family control over women and of the women's own traditional gender role attitudes are revealing in this respect.

Women who are more strongly controlled by their families, as indicated by the fact that brides money was paid at their wedding or that they have only a religious marriage (and hence no legal marriage rights) have a higher probability of being housewives and women who are related to their husbands have a lower probability of being employed in an upper nonmanual occupation. Also the finding that 27 percent of the women who are not employed openly state that they don't work because "their family does not want them to", stresses the importance of family control over female labor. That patriarchal control not only works from the outside, but also via the internalization of the patriarchal values by the women themselves, becomes very clear from the fact that the chances of being employed in the formal economy or in an upper nonmanual occupation are significantly reduced for women with traditional gender role attitudes.

Additional insights in the working of patriarchal ideology is obtained from the findings that women in the Eastern region of Turkey more than elsewhere declare themselves to be housewives. This is also true for non-Turkish speaking women (mostly women with a Kurdish or Arabic background living in or coming from the East), of which as much as 86 percent is not employed. This result seems not in line with the U-curve hypothesis on the effect of modernization, which would predict that in the most agricultural and least modernized Eastern part of Turkey many women would be engaged in agricultural work. Not speaking Turkish cannot be a major reason for the low employment of the Eastern women in agriculture, as they speak the local languages at home. This suggest that cultural motives play an important role here. The East of Turkey is also the most patriarchal part of the country, where in the rural areas brides money is paid at two third of all marriages, where one third of women has only a religious marriage and where two third of women cannot read (Gündüz-Hoşgör and Smits, 2007). Our findings suggest that in this most patriarchal region, family control over women goes so far that 
even their activities at the family farm are not recognized as economic contributions to the household. Their non-employment makes these women very dependent on their husbands and other family members. Women who are employed, even if it is simple work in agriculture, are in a stronger position in negotiations about family decisions, as they contribute to subsistence (Blood \& Wolfe, 1960; Shorter, 1973; Inglehart \& Norris, 2003). They also can be expected to be more confident and have higher self-esteem and when they migrate to the city to find their own ways more easily than women who never worked in public sphere (Walby, 1998; Kabeer 2003).

The low LMP of women in Turkey found in this study, raises questions about the economic role of the two-third of Turkish women who state to be neither employed in the formal economy nor in farming. It is possible that part of these women are economically active in the informal economy. There are indications that in recent years women in Turkey have supplied low wage labor for a sex segregated labor-intensive informal labor market that benefits capital accumulation (Kalaycıoğlu \& Rittersberger-Tılıç, 2000; Erman, 1997). As those women usually are concentrated in food provision and textiles of manufacturing, it seems that the tasks which women usually perform at home are moved into wage-labor sphere in a commercialized form (Çınar, 1994; White, 1994; GündüzHoşgör, 1997; Kalaycıoğlu \& Rittersberger-Tılıç, 2000; Buğra \& Keyder, 2003).

With the impact of globalization, in other developing countries, like in Latin America or in Asia, women usually find work in global export-zones as the result of the recent international division of labor. Those women provide cheap labor while working at the zone factories, where they sometimes even live away from their families for longer time at dormitories ( Ward, 1998). We argue that this is not much possible for countries like in Turkey, where family, religion and patriarchal ideologies have a strong influence. In this situation, engaging in home-based work might be a good alternative for the poor migrant women in the cities. In this way, these migrant women, who have no possibility to join the formal secure labor market, as the result of lack of education, having younger children at home, or living under traditional and patriarchal values, may serve the global economy through informal home-based labor (Keyder \& Bugra, 2003). 
Future studies should pay specific attention to this matter. Besides assessing the number of women engaged in this kind of home-based work, also attention should be given to the consequences of these activities for the coming generations As the work takes place in the domestic sphere and does not offer the women much opportunity to access the public sphere - as was even for farm women to a certain extent the case --, it remains to be seen to what extent the women's autonomy is increased by it and whether it will have any impact on the reproduction of the patriarchal ideology into the next generation. If there would be no immediate action it seems that not just those women but even their daughters are at risk.

\section{References}

Acar, F. (2004). Women's Education” in Bridging the Gender Gap in Turkey: A Milestone towards faster Socio-economic Development. Ankara: World Bank Report.

Ahmad, L. (1982). Feminism and the Feminist Movements in the Middle East, A Preliminary Exploration : Turkey, Egypt, Algeria, Peoples Democratic Republic of Yemen, Women's Studies International Forum, 5(2), 153-168.

Assaad, Ragui \& Arntz Melanie (2005). Constrained geographical mobility and gendered labor market outcomes under structural adjustment: Evidence from Egypt. World Development, 33(3), 431-454.

Baslevent, Cem \& Onaran, Ozlem (2004). The effect of export-oriented growth on female labor market outcomes in Turkey. World Development, 32, 1375-1393.

Baykan, A. (1994) The Turkish Women: An Adventure in Feminist Historiography, Gender and History, 6(1), 101-116.

Blood P. M. \& Wolfe D. M. (1960). Husbands and wives. The dynamics of married living. New York: Free Press.

Boserup, Ester (1970). Women's role in economic development. London: Allen and Unwin.

Boserup, Ester (1977). Preface. Signs, 3, xi-xiii. 
Buğra, A. \& Keyder Ç. (2003). New Poverty and the Changing Welfare Regime of Turkey. Ankara: Ajans Türk.

Çakir, S. (1994). Osmanli Kadın Hareketi. Istanbul: Metis yayinlari.

Caldwell, John C. (1978). A theory of fertility: From high plateau to destabilization. Population and Development Review, 4, 553-577.

Chen, Martha Alter, Sebstad, Jennifer, \& O'Connell, Lesley (1999). Counting the invisible workforce: The case of homebased workers. World Development, $27(3), \ldots \ldots$

Çınar M. (1994). Unskilled Urban Migrant Women and Disguised Employment: Home-Working Women in Istanbul, Turkey. World Development, 22(3): 369380.

Davis, Kingsley (1984). Wives and work: The sex revolution and its consequences. Population and Development Review, 10, 111-130.

Dayıoğlu M., \& Türüt_Aşık S., 2004. Gender Differences in Academic Performance in a Large Public University in Turkey. METU ERC Working Papers in Economics 04/17. Ankara

DHS+, (2007). Demographic and Health Surveys (online) Available at: http://www.measuredhs.com

Durand, J. D. (1975). The labor force in economic development. Princeton University Press.

Ecevit, Y. , Gündüz-Hosgör A., Tokluoğlu C. (2003). Professional women in computer programming occupations: the case of Turkey. Career Development International, 8(2), 78-87.

Erman Tahire (1998). The impact of migration on Turkish rural women. Gender \& Society, 12(2), 146-167.

Erman Tahire (1997). The Meaning of City Living for Rural Migrant Women and their Role in Migration: the Case of Turkey. Women's Studies International Forum, 20(2), 263-273.

Forsythe, Nancy, Korzeniewicz, Roberto P., \& Durrant, Valerie (2000). Gender inequalities and economic growth: A longitudinal evaluation. Economic Development and Cultural Change, 48, 573-617. 
Göle, N. (1991). Modern Mahrem: Medeniyet ve Örtünme (Modern Confidante: Civilization and Covering). Istanbul: Metis Yayınları.

Gündüz-Hoşgör, Ayse (1997). Development and Women's Employment Status:

Evidence from the Turkish Republic 1923-1990. Unpublished Ph.D. Thesis in Sociology. University of Western Ontario. London. Canada.

Gündüz-Hoşgör, Ayse (2001). Convergence Between Theoretical Perspectives in Women-gender and development Literature Regarding Women's Economic Status in the Middle East., METU Studies in Development, 28, 111-132.

Gündüz-Hoşgör, Ayse. \& Jeroen Smits (2002). Intermarriage Between Turks and Kurds in Contemporary Turkey: Interethnic Relations in an Urbanizing Environment, European Sociological Review, 18(4), 417-432.

Gündüz-Hosgör, Ayse \& Jeroen Smits (2007). The status of rural women in Turkey: What is the role of regional differences, in Valentine Moghadam (ed) From Patriarchy to Empowerment: Women's Participation, Movements, and Rights in the Middle East, North Africa, and South Asia. Syracuse: Syracuse University press.

Horton, Susan (1999). Marginalization revisited: Women's market work and pay, and economic development. World Development, 27(3), 571-582.

ILO (2006). LABORSTA, Economic active population estimates and projections, $4^{\text {th }}$ edition. International Labor Office Website: http://laborsta.lo.org.

ILO (2002). Women and men in the informal economy: A statistical picture.

Geneva: International Labour Organization.

Ilyasoğlu, A. (1994). Örtülü Kimlik. Istanbul: Metis Yayinlari.

Inglehart, Ronald \& Pippa Norris (2003). Rising tide: Gender equality and cultural change around the world. Cambridge: Cambridge University Press.

Jayawardena, K. (1986). Feminism and Nationalism in the Third World, London: Zed Press.

Kabeer, N. (2003). Gender Mainstreaming in Poverty Eradication and the

Millennium Development Goals. London: Commonwealth Secretariat/IDRC/CIDA.

Kalaycıoğlu S. \& Rittersberger-Tılıç, H. 2000. Evlerimizdeki Gündelikçi Kadınlar: Cömert “Abla"ların "Hanım"ları. Su yayınları: Ankara. 
Kalmijn, M.(1998). Intermarriage and Homogamy: Causes, Patterns, Trends. Annual Review of Sociology, 25, 395-421.

Kandiyoti, D.(1997). Cariyeler, Bacılar, Yurttaşlar: Kimlikler ve Toplumsal Dönüşümler. Istanbul: Metis Yayınları.

Kandiyoti, D.(1988). Bargaining with Patriarchy, Gender and Society, 2, 274-289.

Kabeer, Naila, \& Simeen Mahmud (2004). Globalization, gender, and poverty: Bangladeshi women workers in export and local markets. Journal of International Development, 16, 93-109.

Kerr, Clark, Dunlop John. T., Harbison, Frederick H., \& Myers, Charles A. (1960). Industrialism and industrial man. The problems of labor and management in economic growth. Cambridge: Harvard University Press.

Keyder, Ç. \& Buğra, A. (2003). New Poverty and the Changing Welfare Regime of Turkey. Report prepared for the United Nations Development Programme. Ankara: Ajans Turk Press.

Klein, Viola (1963). Industrialization and the changing role of women. Current Sociology, 12, 24-34.

Lerner, Daniel (1958). The passing of traditional society. Modernizing the Middle East. New York: The Free Press.

Lewis, B.(1968). The Emergence of Modern Turkey. Oxford: Oxford University Press.

Lincove, Jane Arnold (forthcoming). Growth, Girls' education, and female labor: A longitudinal analysis. The Journal of Developing Areas.

Moghadam, Valentine M. (1993). Modernizing Women: Gender and Social Change in the Middle East, Boulder and London: Lynne Rienner Publishers. Moghadam, Valentine M. (2004). Patriarchy in transition: Women and the changing family in the Middle East. Journal of Comparative Family Studies, 35, 137-162.

Morrisson, Christian \& Jutting, Johannes P. (2005). Women's discrimination in developing countries: A new data set for better policies. World Development, 33(7), 1065-1081.

OECD Development Center, Issy- les-Moulineaux, France July 2005, pp. 10651081. 
Oppenheimer, Valerie K. (1970). The female labor force in the United States. Berkeley: Institute for International Studies.

Ozbilgin, M. F.; Tatli, A. \& Küskü, F. (2005). Gendered occupational outcomes: the case of professional training and work in Turkey, in Eccles, J. \& Watt, H. (eds.), Explaining Gendered Occupational Outcomes. Michigan: American Psychological Association (APA) Press.

Özbilgin, M., \& Woodward, D. (2004). 'Belonging' and 'otherness': Sex equality in banking in Turkey and Britain. Gender, Work and Organization, 11 (6), 668688.

Pampel, Fred C. \& Kazuko Tanaka (1986). Economic development and female labor force participation: A reconsideration. Social Forces, 64, 599-619.

Psacharopoulos, George \& Zafiris Tzannatos (1989). Female labor force participation: An international perspective. The World Bank Research Observer, 4, 187-201.

Rau, William \& Robert Wazienski (1999). Industrialization, female labor force participation, and the modern dividion of labor by sex. Industrial Relations, 38, 504-521.

Ross, Michael (2006). Does oil hurt the status of women? Working paper. Los Angeles: UCLA Department of Political Science.

Scott, Joan W., \& Tilly, Luoise (1987). Women's work and family in nineteenthcentury Europe. Comparative Study of Society and History, 17, 36-64.

Sethuraman, S. V. (1998). Gender, Informality and Poverty: A global review of gender bias in female informal employment and incomes in developing countries. Geneva: World Bank.

Sinha, J. N. (1967). Dynamics of female participation in economic activity. In Proceedings of the World Population Conference, Belgrade (Vol. 4), 336-337.

SIS, State Institute of Statistics. (1993). Household Labor Force Survey Results. Ankara: SIS Press.

SIS, State Institute of Statistics. (2006) Population and Development indicators. Available from: http://nkg.die.gov.tr/default.asp.

Shorter, Edward (1973). Female emancipation, birth control, and fertility in European history. American Historical Review, 78, 605-640. 
Smits, J.,Ultee W, \& Lammers J. (1996). Effects of occupational status differences between spouses on the wife's labor force participation and occupational achievement: findings from 12 European countries, Journal of Marriage and the Family, 58, 101-115.

Smits J., \& Gündüz-Hoşgör A.(2003). Linguistic Capital: Language as a Socioeconomic Resource Among Kurdish and Arabic Women in Turkey, Ethnic and Racial Studies, 26(5), 829-853.

Standing, Guy (1999). Global feminization through flexible labor: A theme revisited. World Development, 27(3), 583-602.

Tansel, Aysit (2002). Economic development and female labor force participation in Turkey: Time series evidence and cross-province estimates. ERC Working Papers in Economics 01/05. Ankara: Economic Research Center, METU.

TBB (Türkiye Bankalar Birliği) (2002). Turkiye Bankalar Birligi Istatistiksel Veriler, Istanbul: TBB.

TDHS (2000). Turkish Demographic and Health Survey. Ankara: Hacettepe University Press.

Tekeli, S. (1982). Kadinlar ve Siyasal Toplumsal Hayat. Istanbul: Birikim Yayinlari.

Tilly, Louise A., \& Joan W. Scott. (1978). Women, work, and family. New York: Holt, Rinehart \& Winston.

UN (2007). Social indicators. United Nations Statistics Divisions, Website: http://unstats.un.org/unsd.

Walby, S. (1998). Gender Transformations. London: Routledge.

Ward, K.B. (1998). Women in the Global Economy. Women and Work 3: 17-48.

White, J. (1994). Money Makes Us Relatives: Women's Labor in Urban Turkey. Austin: University of Texas Press.

Wilensky, H. L. (1968). Women's work: Economic growth, ideology and social structure. Industrial Relations, 7, 235-248.

Youssef, Nadia Haggag (1974). Women and work in developing societies. Population Monograph Series, No. 15, Berkeley: University of California Institute of International Studies. 
Table 1. Sectoral distribution of total and female employment in Turkey and female activity rate 1985-2005

\begin{tabular}{lccccc}
\hline Total employment (15+) & 1985 & 1990 & 1995 & 1999 & 2005 \\
\hline Agriculture & 45.0 & 46.9 & 43.4 & 41.4 & 29.5 \\
Manufacturing & 20.0 & 20.7 & 22.3 & 22.8 & 24.7 \\
Commercial services & 19.0 & 17.9 & 20.1 & 21.2 & 29.7 \\
Social and personal services & 16.0 & 14.6 & 14.2 & 14.6 & 16.1 \\
Total & 100.0 & 100.0 & 100.0 & 100.0 & 100.0 \\
\hline Female employment (15+) & & & & & \\
\hline Agriculture & 79.0 & 75.8 & 71.2 & 67.6 & 51.6 \\
Manufacturing & 8.1 & 9.7 & 9.9 & 10.9 & 15.1 \\
Commercial services & 4.0 & 5.4 & 7.3 & 8.8 & 15.6 \\
Social and personal services & 8.9 & 9.1 & 11.6 & 12.7 & 17.7 \\
Total & 100.0 & 100.0 & 100.0 & 100.0 & 100.0 \\
\hline Female activity rate (20-49) & 45.1 & 39.2 & 35.7 & 34.5 & 29.8 \\
\hline
\end{tabular}

Source: ILO LABORSTA Database (http://laborsta.ilo.org) 
Table 2. Percentages of women in different occupational positions according to personal, husband's and household characteristics

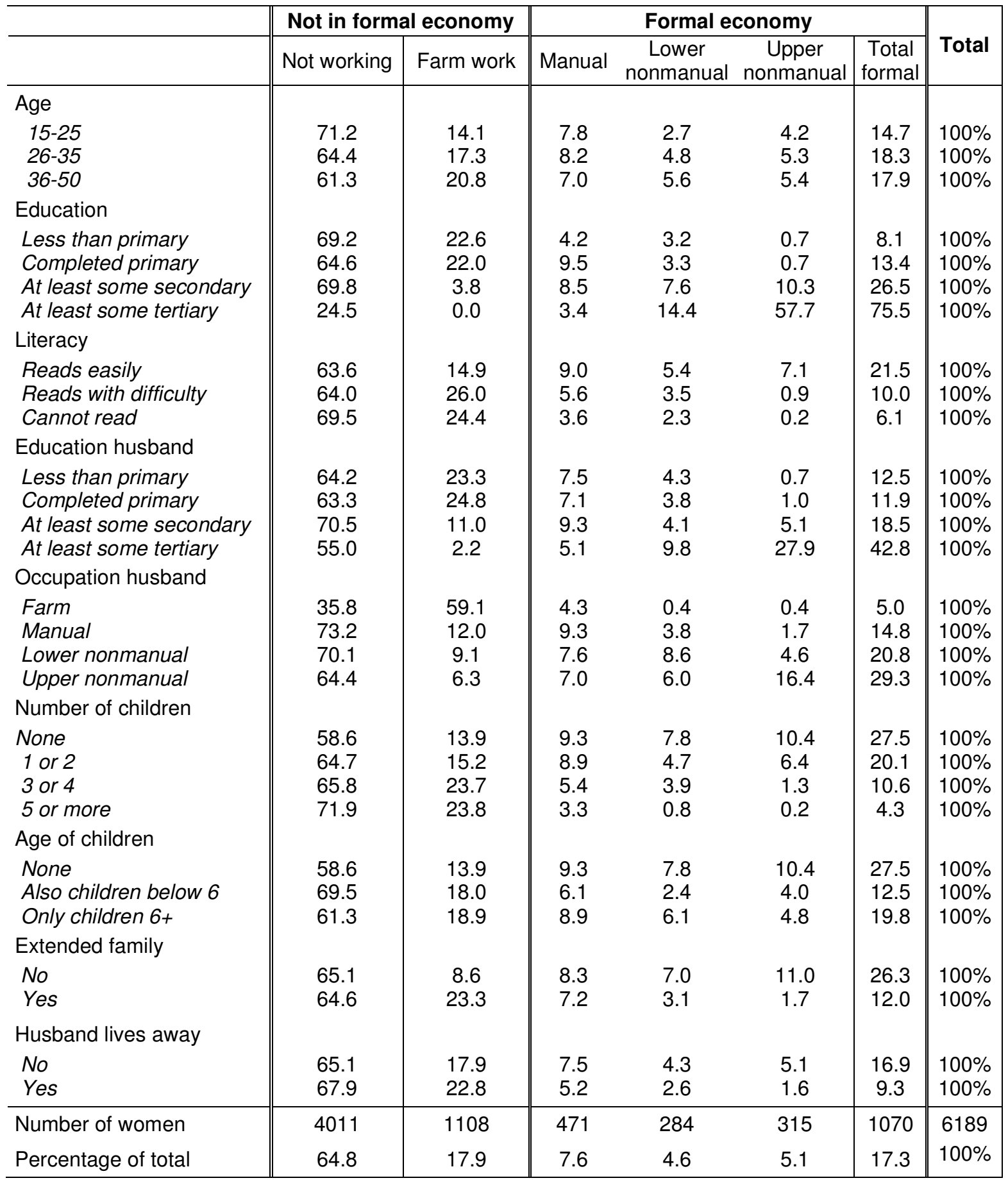


Table 3. Percentages of women in different occupational positions according to region and urbanization/migration

\begin{tabular}{|c|c|c|c|c|c|c|c|}
\hline & \multicolumn{2}{|c|}{$\begin{array}{c}\text { Not in formal } \\
\text { economy }\end{array}$} & \multicolumn{4}{|c|}{ Formal economy } & \multirow{2}{*}{ Total } \\
\hline & $\begin{array}{c}\text { Not } \\
\text { working }\end{array}$ & Farm work & Manual & $\begin{array}{c}\text { Lower } \\
\text { nonmanual }\end{array}$ & $\begin{array}{c}\text { Upper } \\
\text { nonmanual }\end{array}$ & \begin{tabular}{|c|} 
Total \\
formal
\end{tabular} & \\
\hline \multicolumn{8}{|l|}{ Region } \\
\hline West & 63.7 & 11.4 & 10.8 & 7.6 & 6.5 & 25.0 & $100 \%$ \\
\hline South & 71.6 & 17.1 & 3.9 & 3.6 & 3.7 & 11.3 & $100 \%$ \\
\hline Central & 60.0 & 24.2 & 7.6 & 2.6 & 5.7 & 15.8 & $100 \%$ \\
\hline North & 44.7 & 41.9 & 5.5 & 3.8 & 4.0 & 13.4 & $100 \%$ \\
\hline East & 79.4 & 12.8 & 4.1 & 1.4 & 2.3 & 7.9 & $100 \%$ \\
\hline \multicolumn{8}{|l|}{ Migration/urbanization } \\
\hline Always lived in city & 71.2 & 1.6 & 7.7 & 8.0 & 11.5 & 27.2 & $100 \%$ \\
\hline Migrated to city $11-45$ years ago & 75.5 & 3.5 & 8.1 & 7.4 & 5.5 & 21.1 & $100 \%$ \\
\hline Migrated to city $0-10$ years ago & 77.1 & 3.9 & 10.6 & 4.3 & 4.1 & 18.9 & $100 \%$ \\
\hline Town & 70.5 & 13.8 & 7.9 & 4.0 & 3.7 & 15.7 & $100 \%$ \\
\hline Countryside & 46.7 & 44.9 & 5.9 & 0.9 & 1.6 & 8.4 & $100 \%$ \\
\hline
\end{tabular}


Table 4. Percentages of women in different occupational positions according to characteristics of their marriage

\begin{tabular}{|c|c|c|c|c|c|c|c|}
\hline & \multicolumn{2}{|c|}{ Not in formal economy } & \multicolumn{4}{|c|}{ Formal economy } & \multirow[b]{2}{*}{ Total } \\
\hline & Not working & Farm work & Manual & $\begin{array}{c}\text { Lower } \\
\text { nonmanual }\end{array}$ & $\begin{array}{c}\text { Upper } \\
\text { nonmanual }\end{array}$ & $\begin{array}{c}\begin{array}{c}\text { Total } \\
\text { formal }\end{array} \\
\end{array}$ & \\
\hline $\begin{array}{l}\text { Age at first marriage } \\
<16 \\
16-20 \\
>20\end{array}$ & $\begin{array}{l}64.7 \\
66.9 \\
61.0\end{array}$ & $\begin{array}{l}23.8 \\
19.0 \\
12.2\end{array}$ & $\begin{array}{l}6.0 \\
7.9 \\
8.0\end{array}$ & $\begin{array}{l}4.3 \\
3.7 \\
6.5\end{array}$ & $\begin{array}{c}1.2 \\
2.5 \\
12.3\end{array}$ & $\begin{array}{l}11.5 \\
14.1 \\
26.8\end{array}$ & $\begin{array}{l}100 \% \\
100 \% \\
100 \%\end{array}$ \\
\hline $\begin{array}{l}\text { Age got first child } \\
<16 \\
16-20 \\
>20\end{array}$ & $\begin{array}{l}65.2 \\
66.7 \\
63.8\end{array}$ & $\begin{array}{l}22.3 \\
20.7 \\
15.4\end{array}$ & $\begin{array}{l}6.6 \\
7.3 \\
7.5\end{array}$ & $\begin{array}{l}5.2 \\
3.6 \\
5.1\end{array}$ & $\begin{array}{l}0.7 \\
1.8 \\
8.2\end{array}$ & $\begin{array}{l}12.5 \\
12.7 \\
20.8\end{array}$ & $\begin{array}{l}100 \% \\
100 \% \\
100 \%\end{array}$ \\
\hline $\begin{array}{l}\text { Related to husband } \\
\text { No } \\
\text { Yes }\end{array}$ & $\begin{array}{l}63.8 \\
67.9\end{array}$ & $\begin{array}{l}16.9 \\
21.1\end{array}$ & $\begin{array}{l}8.0 \\
6.4\end{array}$ & $\begin{array}{l}5.1 \\
3.1\end{array}$ & $\begin{array}{l}6.3 \\
1.5\end{array}$ & $\begin{array}{l}19.3 \\
10.9\end{array}$ & $\begin{array}{l}100 \% \\
100 \%\end{array}$ \\
\hline $\begin{array}{l}\text { Brides money paid at wedding } \\
\text { No } \\
\text { Yes }\end{array}$ & $\begin{array}{l}63.4 \\
68.7\end{array}$ & $\begin{array}{l}16.4 \\
22.9\end{array}$ & $\begin{array}{l}8.8 \\
3.8\end{array}$ & $\begin{array}{l}4.9 \\
3.7\end{array}$ & $\begin{array}{l}6.5 \\
1.0\end{array}$ & $\begin{array}{l}20.2 \\
8.4\end{array}$ & $\begin{array}{l}100 \% \\
100 \%\end{array}$ \\
\hline $\begin{array}{l}\text { Only religious marriage } \\
\text { No } \\
\text { Yes }\end{array}$ & $\begin{array}{l}64.0 \\
74.8\end{array}$ & $\begin{array}{l}18.0 \\
17.4\end{array}$ & $\begin{array}{l}7.8 \\
5.4\end{array}$ & $\begin{array}{l}4.8 \\
1.7\end{array}$ & $\begin{array}{l}5.4 \\
0.7\end{array}$ & $\begin{array}{c}18.1 \\
7.8\end{array}$ & $\begin{array}{l}100 \% \\
100 \%\end{array}$ \\
\hline $\begin{array}{l}\text { Arranged marriage themselves } \\
\text { No } \\
\text { Yes }\end{array}$ & $\begin{array}{l}65.9 \\
62.8\end{array}$ & $\begin{array}{l}21.2 \\
12.1\end{array}$ & $\begin{array}{l}7.1 \\
8.5\end{array}$ & $\begin{array}{l}3.5 \\
6.5\end{array}$ & $\begin{array}{c}2.3 \\
10.1\end{array}$ & $\begin{array}{l}12.9 \\
25.1\end{array}$ & $\begin{array}{l}100 \% \\
100 \%\end{array}$ \\
\hline
\end{tabular}


Table 5. Percentages of women in different occupational positions according to speaking Turkish and gender role attitudes

\begin{tabular}{|c|c|c|c|c|c|c|c|}
\hline & \multicolumn{2}{|c|}{ Not in formal economy } & \multicolumn{4}{|c|}{ Formal economy } & \multirow[b]{2}{*}{ Total } \\
\hline & $\begin{array}{c}\text { Not } \\
\text { working }\end{array}$ & Farm work & Manual & $\begin{array}{c}\text { Lower } \\
\text { nonmanual }\end{array}$ & $\begin{array}{c}\text { Upper } \\
\text { nonmanual }\end{array}$ & \begin{tabular}{|c|} 
Total \\
formal
\end{tabular} & \\
\hline \multicolumn{8}{|l|}{ Speaks Turkish } \\
\hline No & 86.3 & 11.6 & 1.7 & 0.0 & 0.3 & 2.1 & $100 \%$ \\
\hline $\begin{array}{l}\text { Yes } \\
\text { Important decisions should be } \\
\text { made by men }\end{array}$ & 63.7 & 18.2 & 7.9 & 4.8 & 5.3 & 18.1 & $100 \%$ \\
\hline No & 66.3 & 11.4 & 8.1 & 6.2 & 8.0 & 22.3 & $100 \%$ \\
\hline Yes & 62.5 & 27.9 & 6.9 & 2.0 & 0.7 & 9.5 & $100 \%$ \\
\hline \multicolumn{8}{|l|}{ Men are wiser than women } \\
\hline No & 66.5 & 11.6 & 8.2 & 6.2 & 7.4 & 21.8 & $100 \%$ \\
\hline Yes & 60.8 & 30.1 & 6.8 & 1.8 & 0.7 & 9.2 & $100 \%$ \\
\hline \multicolumn{8}{|l|}{$\begin{array}{l}\text { Women should not argue with } \\
\text { men }\end{array}$} \\
\hline No & 66.6 & 10.3 & 7.8 & 6.6 & 8.6 & 23.1 & $100 \%$ \\
\hline Yes & 62.5 & 26.6 & 7.4 & 2.3 & 1.2 & 11.0 & $100 \%$ \\
\hline \multicolumn{8}{|l|}{$\begin{array}{l}\text { Better for male child to have } \\
\text { education }\end{array}$} \\
\hline No & 66.8 & 13.5 & 7.8 & 5.4 & 6.5 & 19.7 & $100 \%$ \\
\hline Yes & 57.9 & 32.7 & 6.9 & 2.0 & 0.6 & 9.4 & $100 \%$ \\
\hline
\end{tabular}


Table 6. Main reasons why married women are currently not employed

\begin{tabular}{lcc}
\hline & Frequency & Percentage \\
\hline Takes care of children or household & 1516 & 37.7 \\
Husband or elder does not want & 1103 & 27.4 \\
No need to work & 463 & 11.5 \\
Sick, handicapped, unemployed & 435 & 10.8 \\
No talent or education & 183 & 4.5 \\
Other & 326 & 8.1 \\
\hline Total & 4025 & 100 \\
\hline
\end{tabular}


Table 7: Logistic regression coefficients of selected independent variables on the odds of being a housewife, of working in agriculture, of being employed in the formal economy, and of working in an upper nonmanual occupation (multiplicative versions of the coefficients between bracelets)

\begin{tabular}{|c|c|c|c|c|c|c|c|c|}
\hline \multirow[b]{3}{*}{ Intercept } & \multicolumn{2}{|c|}{ Model I } & \multicolumn{2}{|c|}{ Model II } & \multicolumn{2}{|c|}{ Model III } & \multicolumn{2}{|c|}{ Model IV } \\
\hline & \multicolumn{2}{|c|}{ Housewife } & \multicolumn{2}{|c|}{ Farming } & \multicolumn{2}{|c|}{ Formal job } & \multicolumn{2}{|c|}{ Upper nonmanual } \\
\hline & $1.84^{* *}$ & $(6.27)$ & $-4.54^{\star \star}$ & $(0.01)$ & $-3.64^{* *}$ & $(0.03)$ & $-5.18^{* *}$ & $(0.01)$ \\
\hline Age & $-0.01^{*}$ & $(0.99)$ & $0.02^{* *}$ & $(1.02)$ & & & & \\
\hline \multicolumn{9}{|l|}{ Education } \\
\hline Less than primary & \multicolumn{2}{|c|}{ Reference } & \multicolumn{2}{|c|}{ Reference } & \multicolumn{2}{|c|}{ Reference } & \multicolumn{2}{|c|}{ Reference } \\
\hline Completed primary & $-0.24^{\star *}$ & $(0.79)$ & 0.17 & $(1.18)$ & $0.33^{* *}$ & $(1.39)$ & -0.61 & $(0.54)$ \\
\hline At least some secondary & $-0.57^{* *}$ & $(0.57)$ & $-0.80^{* *}$ & $(0.45)$ & $0.89^{* *}$ & (2.43) & $1.62^{\star *}$ & (5.05) \\
\hline At least some tertiary & $-2.64^{\star *}$ & $(0.07)$ & -4.96 & $(0.01)$ & $2.91^{* *}$ & (18.3) & $3.71^{\star *}$ & $(40.9)$ \\
\hline \multicolumn{9}{|l|}{ Education husband } \\
\hline Less than primary & & & & & & & & \\
\hline Completed primary & 0.17 & $(1.18)$ & & & $-0.55^{\star *}$ & $(0.57)$ & & \\
\hline At least some secondary & $0.40^{\star *}$ & $(1.48)$ & & & $-0.60^{* *}$ & $(0.55)$ & & \\
\hline At least some tertiary & $0.33^{*}$ & (1.39) & & & $-0.54^{\star \star}$ & $(0.58)$ & & \\
\hline \multicolumn{9}{|l|}{ Occupation husband } \\
\hline Farm & \multicolumn{2}{|c|}{ Reference } & \multicolumn{2}{|c|}{ Reference } & \multicolumn{2}{|c|}{ Reference } & \multicolumn{2}{|c|}{ Reference } \\
\hline Manual & $1.36^{\star *}$ & $(3.89)$ & $-1.66^{\star *}$ & $(0.19)$ & $0.91^{* *}$ & $(2.48)$ & 0.74 & $(2.10)$ \\
\hline Lower nonmanual & $1.14^{\star *}$ & (3.12) & $-1.65^{\star *}$ & $(0.19)$ & $1.20^{* *}$ & (3.33) & $1.31^{*}$ & $(3.70)$ \\
\hline Upper nonmanual & $1.16^{\star \star}$ & (3.19) & $-1.87^{\star \star}$ & $(0.15)$ & $1.18^{\star *}$ & (3.27) & $2.01^{\star *}$ & (7.49) \\
\hline \multicolumn{9}{|l|}{ Presence and age of children } \\
\hline No children & Refer & & Refer & & Refer & & Refer & ice \\
\hline 1-2 including under age 6 & $0.52^{* *}$ & $(1.69)$ & & & $-0.58^{* *}$ & $(0.56)$ & -0.30 & $(0.74)$ \\
\hline >2 including under age 6 & $0.45^{\star \star}$ & (1.57) & & & $-1.05^{\star *}$ & $(0.35)$ & $-1.42^{* *}$ & $(0.24)$ \\
\hline 1-2 only over age 6 & 0.11 & $(1.12)$ & & & -0.07 & $(0.93)$ & -0.05 & $(0.95)$ \\
\hline >2 only over age 6 & 0.21 & $(1.23)$ & & & $-0.37^{\star *}$ & $(0.69)$ & -0.42 & $(0.66)$ \\
\hline Region & & & & & & & & \\
\hline West & $-0.86^{\star *}$ & $(0.43)$ & $0.74^{\star *}$ & (2.09) & $0.66^{\star *}$ & (1.93) & & \\
\hline South & $-0.26^{*}$ & $(0.77)$ & $0.60^{* *}$ & (1.82) & 0.05 & (1.05) & & \\
\hline Central & $-0.63^{\star *}$ & $(0.53)$ & $0.95^{\star \star}$ & $(2.58)$ & 0.23 & $(1.26)$ & & \\
\hline North & $-1.33^{\star *}$ & $(0.27)$ & $1.90^{\star *}$ & (6.69) & 0.15 & $(1.16)$ & & \\
\hline East & Refer & & Refer & & Refer & & Refer & ce \\
\hline Urbanization/migration status & & & & & & & & \\
\hline Always in city & Refer & & Refer & & & & & \\
\hline Migrated to city $>10$ years ago & -0.03 & $(0.97)$ & 0.43 & $(1.53)$ & - & - & & \\
\hline Migrated to city $0-10$ years ago & -0.12 & $(0.89)$ & 0.47 & (1.59) & - & - & & \\
\hline Lives in town & $-0.27^{*}$ & $(0.76)$ & $1.64^{\star *}$ & (5.16) & - & - & & \\
\hline Lives in countryside & $-1.15^{\star *}$ & (0.32) & $2.78^{* *}$ & (16.1) & - & - & & \\
\hline Husband away from home & - & - & - & - & $-0.53^{\star *}$ & $(0.59)$ & & \\
\hline Wife speaks Turkish & $-1.07^{\star *}$ & $(0.34)$ & $0.99^{* *}$ & $(2.70)$ & $1.11^{* *}$ & (3.03) & & \\
\hline Married young & - & - & $0.21^{*}$ & (1.23) & - & - & & \\
\hline Only religious marriage & $0.28^{*}$ & $(1.32)$ & $-0.50^{\star *}$ & $(0.61)$ & - & - & & \\
\hline Bridesmoney paid at wedding & $0.17^{*}$ & (1.19) & - & - & - & - & & \\
\hline Woman related to husband & - & - & - & - & - & - & $-0.52^{*}$ & $(0.59)$ \\
\hline Traditional gender role attitude & $-0.19^{\star *}$ & $(0.83)$ & $0.40^{\star *}$ & $(1.50)$ & $-0.14^{*}$ & $(0.87)$ & $-0.44^{*}$ & $(0.64)$ \\
\hline N Total & 600 & & 606 & & 6049 & & 606 & \\
\hline $\mathrm{N}$ category 1 & 390 & & 110 & & 1066 & & 315 & \\
\hline Model Chi-Square (DF) & 1297.8 & 26) & 2255. & (19) & 978.1 & & 1071.3 & 12) \\
\hline
\end{tabular}

Additional variables added to the selection model were "arranged marriage themselves" and "married under age 16 " but these variables were not significant in any model

${ }^{*} p<0.05{ }^{* *} p<0.01$ 